\title{
The Use of Scientific-Based Approach in ELT Class to Improve Students' Achievement and Classroom Interaction
}

\author{
Haerazi \\ English Lecturer, Graduate School, Mandalika University of Education \\ haerazi@ikipmataram.ac.id \\ Rully May Vikasari \\ English Teacher, SMPN 4 Praya, Central Lombok, NTB \\ momvika@gmail.com \\ Zukhairatunniswah Prayati \\ English Teacher, SMPN 1 Jonggat, Lombok Tengah, NTB \\ anisprayati@gmail.com \\ DOI: https://doi.org/10.18326/rgt.v12i2.141-157
}

\begin{tabular}{|c|c|}
\hline Submission & \\
\hline Track: & ABSTRACT \\
\hline Received: & \\
\hline $27-7-2019$ & $\begin{array}{l}\text { This study investigated the use of the scientific-based approach in the } \\
\text { ELT class to solve students' learning problems. Those problems are }\end{array}$ \\
\hline Final Revision: & $\begin{array}{l}\text { students' difficulties to complete their learning tasks, lack of vocabulary } \\
\text { to complete reading tasks, lack of grammatical competence, afraid of }\end{array}$ \\
\hline 20-11-2019 & $\begin{array}{l}\text { proposing questions, afraid of speaking, and difficulties to complete the } \\
\text { listening tasks. These caused students to have low achievement and }\end{array}$ \\
\hline Available online: & $\begin{array}{l}\text { inactive classroom interaction. The study was aimed at improving } \\
\text { students' achievement and classroom interaction of } 8^{\text {th }} \text {-grade students }\end{array}$ \\
\hline $01-12-2019$ & of SMPN 4 Praya, Central Lombok, West Nusa Tenggara. This study \\
\hline Corresponding & $\begin{array}{l}\text { was classroom action research. The procedure of actions included two } \\
\text { steps, namely the reconnaissance and the action. The reconnaissance }\end{array}$ \\
\hline Author: & $\begin{array}{l}\text { presented the students' learning problems and the action consisted of } \\
\text { four stages, namely planning, implementing, evaluating, and reflecting. }\end{array}$ \\
\hline Haerazi & $\begin{array}{l}\text { The research instruments of this study used observation sheets, a } \\
\text { questionnaire, and a test. The collected data were analyzed }\end{array}$ \\
\hline Name \& E-mail & quantitatively and qualitatively. The result of this study showed that the \\
\hline Address & $\begin{array}{l}\text { use of the scientific-based approach was able to improve students' } \\
\text { achievement and classroom interaction. The students' average score }\end{array}$ \\
\hline Haerazi & was 82.76. Each student's score was higher than the minimum passing \\
\hline haerazi@ikip & grade (70). Meanwhile, the interaction classroom was active. It was \\
\hline ram.ac.id & $\begin{array}{l}\text { supported by significant changes. Those changes were that students } \\
\text { become more cooperative, active, and optimistic to complete reading } \\
\text { tasks, listening tasks, speaking activities, and writing assignments in the } \\
\text { form of group discussion. } \\
\text { Keywords: Scientific-Based Approach, Achievement, Classroom Interaction }\end{array}$ \\
\hline & \\
\hline
\end{tabular}




\section{INTRODUCTION}

The change of curriculum in Indonesia is based on the demands to compete internationally. To reach international competitiveness, the change of national curriculum needs reinforcement. In doing so, the ministry of national education recommends the new curriculum, namely Curriculum 2013 (henceforth K13). The concept of K13 is developed in accordance with the educational practice development and educational theoretical paradigm. Basically, the concept of K13 is to complete the previous curriculum, namely KTSP (educational unit level curriculum). The main touch of applying K13 is to increase students' competences in conducting observation, asking or interviewing, thinking logically, and communicating and presenting what they have got or knew as the result of understanding materials. To achieve the goals, the scientific-based approach is employed in K13.

The scientific-based approach has been increasingly applied in all junior and senior educational levels in Indonesia from 2013 to now with some revisions conducted by the ministry of education, social, and culture in each year at both state and private educational schools. It is assumed that the approach is able to cover newly all subjects including English. It emphasizes on learner-centered approach. The main point of this approach is to change the learning paradigm from the learning process to transfer knowledge to the learning process to seek knowledge. In other words, the instructional approach should be changed from the teachercentered approach to the learner-centered approach.

In Curriculum 2013, the use of the scientific-based approach is adopted and recommended for ELT teachers. Learners are seen as the agents who need to be invited actively in the instructional process in the class. The teachers play a role as a facilitator that brings and guides learning activities. Based on some research findings, this approach was able to improve students' critical thinking in public senior high school (Wahono et al. 2017), grammatical mastery (Sodik \& Wijaya, 2017), and English achievement as senior high school (Zaim, 2017). However, in teaching practice, some English teachers still face difficulties in arranging their classroom management in limited instructional tools to support the scientific-based approach to be more effective.

K13 has been providing for English teachers with elaborating scientific instructional models such as genre-based instruction, project-based instruction, inquiry-based instruction, problem-based instruction, and context-based instruction. These instructions are recommended 
to be implemented under the umbrella of the scientific-based instruction. For instance, the scientific-based approach can be integrated with the genre-based approach in ELT classes. The scientific approach has five stages and the genre-based approach has five stages as well. In teaching practice, the teacher can choose any scientific stages to be started inserting the genrebased learning activities. According to Munir (2015), the application of the scientific approach and genre-based approach can be applied accurately as suggested in the Teacher Book (Kemendikbud, 2016). In addition, Syafii (2018); Kristie and Listyani (2018) recommend online short stories, role-play, storytelling, and song can be integrated with the scientific-based approaches for English students. Therefore, the scientific-based approach is directed students on what to learn and how to learn it.

This study is aimed at investigating the use of the scientific-based approach in the ELT class to improve students' achievement and classroom interaction. The effectiveness of the approach will influence the implementation of K13 for all of the Junior high school students at Central Lombok, NTB. The application of the scientific approach in this study was subjected to ELT class at the $8^{\text {th }}$-grade students of SMPN 4 Praya. Based on the observation in the preliminary study, the students' problems that caused students have low achievement and inactive classroom interaction include difficulties to complete learning tasks; on vocabulary acquisition to complete reading tasks; on grammatical competence to write English sentences; proposing questions to teachers or other classmates; speaking ability in discussion process; and listening problems to understand the native speaking.

\section{LITERATURE REVIEW}

\section{Curriculum K13}

In general, the implementation of the $\mathrm{K} 13$ is a reaction to the reality that Indonesia is facing the respective years of the global world and its crucial issues. Dealing with the educational quality, some international assessment programs presented that Indonesian students have a low quality such as PISA assessment. As a response to this, the K13 was designed to prepare students' character to be critical to participate in the global world in the upcoming years. According to Nur and Madkur (2014), K13 offers "the building of character to prepare students to face various opportunities, which could give positive and negative effects for them ad society in general". 
Nooryastuti (2015) states K13 has characteristics such as: "(1) the content of the curriculum is stated in the core competence and the basic competence in detail; (2) the core competence is description of aspects of the attitude, knowledge, and skill that have to be studied by students in the school, class, and subject level; (3) the basic competence is competence for a theme in all educational levels from elementary to middle level; (4) the core and basic competencies have priority in attitude aspects for level of basic education while cognitive aspects are the main point for middle education level; (5) all of basic competences and learning process are developed to attain the core competences; (6) the basic competence is developed accumulatively and reinforced among subjects and educational level; and (7) the syllabus is designed for a theme for elementary school and subjects for middle level".

\section{Teaching English in Junior High Schools}

Teaching English in TEFL context needs an appropriate way to make learners master the target language. Teachers integrate the four language skills, language elements, and language functions. Four language skills cover speaking, writing, reading, and listening. Speaking and writing skills are called productive skills because it relates to how learners produce the target language. Meanwhile, reading and listening skills include receptive skills because both relate to how learners receive information based on both activities.

In Junior high schools, teachers provide language elements for learners such as grammar, vocabulary, punctuation, spelling, and pronunciation. According to Yoshida (2010), the use of cognitive skills such as comparing and constructing the target language with their own language is able to improve learners' linguistic skills. Therefore, teaching English in junior high schools is necessary to build learners' cognitive skills through scientific learning activities.

\section{Scientific-Based Approach}

In K13, the learning approach recommended applying is a scientific-based approach. It emphasizes the learner-centered learning. It is a must because it becomes a part of K13 for Junior High Schools and the goodness of the scientific approach itself. An approach in this study defines a set of correlative assumptions relating to the nature of language teaching and learning. It also defines as an axiomatic clear that doesn't need to be proved. An approach highlights a learning model, method, strategy, and technique.

The scientific-based approach has some learning methods in its teaching practice. The methods include project-based learning, problem-based learning, discovery learning, inquirybased learning, and contextual teaching and learning. These methods are recommended for all 
subjects. For the English subject, English teachers also recommend the genre-based learning model. The terms 'learning method' or 'model' can be interchangeable because it depends on teachers' practice in the class.

Table 1. The Stages of Scientific-Based Approach

\begin{tabular}{|c|c|c|}
\hline Teaching Stages & Learning Activities & Expected Competence \\
\hline Observing & $\begin{array}{l}\text { O Students are invited to do observation } \\
\text { through reading, listening, or seeing } \\
\text { objects. } \\
\text { O Students are asked to determine the object, } \\
\text { its purpose, the way of observation, and the } \\
\text { limitation of the object. } \\
\text { O Students are asked to report the result of } \\
\text { observation activities. } \\
\text { Students are invited to comprehend the } \\
\text { results. }\end{array}$ & $\begin{array}{l}\text { To train the seriousness, } \\
\text { carefulness, and look for } \\
\text { information. }\end{array}$ \\
\hline Questioning & $\begin{array}{l}\text { Students are encouraged to learn actively } \\
\text { and to develop questions of and for the } \\
\text { objects. } \\
\text { Students are asked to raise their skills in } \\
\text { talking, asking questions, and giving } \\
\text { answers logically with proper and correct } \\
\text { grammar. } \\
\text { Students are invited to develop their } \\
\text { abilities to think and draw conclusions. } \\
\text { Students are involved in building an attitude } \\
\text { of openness to give and receive opinions or } \\
\text { ideas. }\end{array}$ & $\begin{array}{l}\text { To develop creativity, } \\
\text { curiosity, the ability to question } \\
\text { formulation to build critical } \\
\text { thinking. }\end{array}$ \\
\hline $\begin{array}{l}\text { Collecting } \\
\text { Information }\end{array}$ & $\begin{array}{l}\text { Students are divided into 3-4 students of } \\
\text { each group. } \\
\text { Students are asked to discuss the learning } \\
\text { objects and helped to make it run well in the } \\
\text { class. } \\
\text { Students are involved to record the finding. } \\
\text { In the supervising process, students are } \\
\text { invited to learn actively. }\end{array}$ & $\begin{array}{l}\text { To develop carefulness, honest, } \\
\text { polite, respects towards people } \\
\text { argument, and communication } \\
\text { competence } \\
\text { To collect information through } \\
\text { some ways. } \\
\text { To develop learning habits. }\end{array}$ \\
\hline Associating & $\begin{array}{l}\text { O Students are asked to analyze and associate } \\
\text { the information occurred within the group. } \\
\text { Students are involved to associate the } \\
\text { relationship between one information and } \\
\text { other information. } \\
\text { O Students are asked to conclude the } \\
\text { information from the patterns found. }\end{array}$ & $\begin{array}{l}\text { To develop the attitude of } \\
\text { honesty, discipline, obedient, } \\
\text { hard work, the ability to } \\
\text { associate information, and the } \\
\text { ability of inductive and } \\
\text { deductive thinking. }\end{array}$ \\
\hline Communicating & $\begin{array}{l}\text { Students are encouraged to conclude the } \\
\text { facts that have been observed and } \\
\text { experimented. }\end{array}$ & $\begin{array}{l}\text { To develop the attitude of } \\
\text { honesty, carefulness, tolerance, }\end{array}$ \\
\hline
\end{tabular}




\begin{tabular}{l}
\hline$\circ \begin{array}{l}\text { Students are asked to read their works or } \\
\text { conclusions in the class. }\end{array}$ \\
The other groups are asked to listen and \\
thinking. \\
provide additional input in line with the \\
works of each group. \\
$\circ \begin{array}{l}\text { Students are asked to give additional to state the clear } \\
\text { explanation after the group discussion }\end{array}$ \\
language literacy well. \\
ended.
\end{tabular}

Zaim (2017) states a scientific approach is a teaching strategy employing scientific steps. This approach has the trait of acting 'science' that allows teachers to increase the learning process by putting the processes down into steps that reflect the detailed instruction for involving students to learn. In K13, the aims of teaching EFL are to attain a functional and informational phase of literacy.

\section{RESEARCH METHOD}

\section{Research Setting}

This study was conducted at the $8^{\text {th }}$-grade students of SMPN 4 Praya, Central Lombok, West Nusa Tenggara, Indonesia. SMPN 4 Praya is one of the junior high schools in Central Lombok, West Nusa Tenggara. There are three grades in it. Each grade has 5-7 classes and each class consists of 21-35 students. This study is carried out at $8^{\text {th }}$-grade students, which has 6 classes. The total numbers of students of SMPN 4 Praya in the academic year of 2018/2019 are 126 students. The study chose one class (VIIIA class) to apply the scientific-based approach. It was taken as the place of this study because the problems found by researchers and teachers were appropriate to be solved using scientific-based approach. This approach was not thoroughly applied by all the English teachers at the $8^{\text {th }}$-grade students.

\section{Research Design}

This study was collaborative action research. It is essentially an on the spot procedure administered to deal with real problems in the schools. According to Costello (2011), collaborative action research is "a form of collective self-reflective inquiry in a real situation to improve educational practices in an institution or schools". This study employed four stages; planning, implementing, evaluating, and reflecting. These stages were done to overcome the identified problems using scientific-based approach. The use of the scientific-based approach 
is to improve students' ELT achievement and classroom interaction of the $8^{\text {th }}$-grade students of SMPN 4 Praya, Central Lombok.

\section{The Procedure of the Action Research}

To conduct action research, the researcher applied the procedure suggested by Elliot (1991) and modified by Haerazi \& Irawan (2019). There are two main activities, namely the reconnaissance and the action.

\section{Reconnaissance}

Reconnaissance is an activity to identify the students' problems through observation and questionnaire. The researcher collaborates with the real teacher to find the ideas, opinions, and suggestions to formulate the problems. In this study, the problems are classified into three levels, which are very difficult, medium, and easy. This study is focused on the medium levels faced by students. The medium levels are selected and categorized into some levels such as most urgent, urgent, and less urgent. The most urgent problems are chosen to be solved by using the scientific-based approach.

\section{Action}

\section{Planning}

The problems found in the initial step would be handled by the implementation of the scientific-based approach to improve students' ELT achievement and classroom interaction at the $8^{\text {th }}$-grade students of SMPN 4 Praya. To do so, the researchers administered the preparation of the implementation of the actions. The research plans include syllabus, lesson plans, materials, and teaching media.

\section{Implementing}

This stage is an action to implement what the researcher and teacher plan. The teacher applies the scientific-based approach in the class to deal with the lesson plan made. In this stage, researchers observe the interaction between the teacher and students and the interaction among the students in the class during the implementation of the learning activity. In addition, the researcher records the process of learning activities. 


\section{Evaluating}

The researcher and teacher discussed the process of learning and teaching activities. The researcher makes some notes dealing with the interaction between students and teachers, and among students in the class. Besides, the researcher records the result of action by interviewing with students and teachers about their opinions, feelings, and suggestion about the actions. At the end of this, the researcher and teacher discussed some changes and improvisation of the interaction, materials, and stages of the scientific-based approach. Then, the research team gives responses toward those changes and improvements.

\section{Reflecting}

This stage is the last stage of action activities that aim to analyze and evaluate the effects, obstacles, difficulties, and other possibilities. When the ELT achievement and classroom interaction of the $8^{\text {th }}$-grade students of SMPN 4 Praya, Central Lombok in the academic year 2018/2019 is considered to be better, the action is stopped. The students' ELT achievement is achieved with 5 meetings. Meanwhile, the classroom interaction better results in 4 meetings in this study. The action is done through two cycles. One cycle is focused on improving the English achievement and the second cycle is administered in enhancing the classroom interaction in teaching and learning processes.

\section{Data Collection Technique}

To collect the research data, the instruments used in this study are a questionnaire, observation, and test. The instruments are considered the validity and reliability. It is proven by the result analysis using Cronbach's Aplha formula where its Alpha (0.730) is higher than the sig. level 0.05. After this process, the researcher observes the ELT learning process and gives questionnaires to the other research team members to identify the learning problems. In the action stages, the researcher observes the classroom learning processes.

The data of students' achievement are collected by using_a test. The kind of test includes a posttest given by the teacher at the end of the teaching and learning process. The indicator of achievement in this study is limited to the individual passing grade of English subject which is 70. Meanwhile, classroom interaction is limited to the process achievement indicators. It can be defined by some improvement in the classroom interaction of the $8^{\text {th }}$-grade students of SMPN 4 Praya in the instructional process. To ensure the trustworthiness of the data and the objectivity of data, the researcher applies triangulation. 


\section{Data Analysis Technique}

The data analysis of this study used the three concurrent flow activities; (1) data reduction, (2) data display, and (3) drawing a conclusion. In the process of data reduction, the data are selected, simplified, and abstracted in the field note. It is done during the research activities. In other words, the researcher reduces the information during the research activities because the data do not support the research data needed. In displaying data, the selected data are depicted and explained in the form of description or narration based on the filed notes and interview transcripts. The last stage of data analysis is taking a conclusion. The data reduced are concluded at the end of each action deal with classroom interaction. Meanwhile, the students' English achievement is concluded at the end of the posttest. The conclusions are about the improvement of ELT achievement and classroom interaction of the $8^{\text {th }}$-grade students of SMPN 4 Praya, Central Lombok, West Nusa Tenggara.

\section{RESULTS AND DISCUSSION}

\section{Reconnaissance}

In this phase, the researcher identifies some problems faced by students in ELT learning process of the $8^{\text {th }}$-grade students of SMPN 4 Praya by observing the classroom activities. In this session, the researcher distributes questionnaires to students and teachers. There are some problems relating to the English language learning components. The problems are found as barriers for students to learn English at SMPN 4 Praya. Those problems are classified into three cases, namely problems with language skills, cognitive skills, and language elements. Therefore, the feasible problems that can be solved in this action research can be seen in Table 2 as follows.

Table 2. The Feasible Problems

\begin{tabular}{cl}
\hline No & \multicolumn{1}{c}{ Learning Problems } \\
\hline 1 & Students do not understand the teachers' instruction to complete their learning tasks. \\
\hline 2 & Students do not have enough vocabular to complete reading tasks. \\
\hline 3 & Students do not have enough grammatical competence to arrange sentences. \\
\hline 4 & Students feel afraid of proposing a question. \\
\hline 5 & Students are afraid of speaking in English during the instructional process in the class. \\
\hline 6 & Students had difficulties in listening to understand speaking. \\
\hline
\end{tabular}


The feasible problems to be solved include problems on understanding teachers' instruction to complete learning tasks; on vocabulary mastery to complete reading tasks; on grammatical competence to write English sentences; asking questions to teachers or other classmates; speaking ability in discussion process; and listening problems to understand speaking. These problems are assumed as obstacles for students to achieve good achievement in English subject.

\section{Actions}

The teacher and researcher agree to use the existing curriculum applied in the school. The instructional materials are adapted from the course-book provided by the school. The teacher modifies the materials in line with the ELT instructional goals and learning objectives. The researcher helps the teacher to design the materials in the form of learning tasks for reading, writing, and speaking. These become some activities that are addressed to handle the students' learning problems. After the lesson plans are prepared well, the teacher implemented in accordance with the time that has been scheduled.

\section{Cycle 1}

This subchapter depicts the implementation of the scientific-based approach as the research action of the study. The aim of this subchapter is to describe the process of the use of the scientific-based approach to solve the six problems as mentioned in this study. The cycle proceeds through planning, implementing, evaluation, and reflection.

\section{Planning}

Based on the result of pre-test and observation, the data indicate students have low achievement in English subject and students have problems in classroom interaction. The plan is to solve those problems using the scientific-based approach. The plan includes four activities that are; (1) choosing the topics and items of instruction, (2) designing the lesson plans that contain the core competence and basic competence, (3) designing observation sheets, and (4) providing teaching materials and teaching media. To find the improvement of students' achievement, the post-test is overseen at the end of the action. Meanwhile, to know the students' improvement of classroom interaction, the post questionnaire is distributed to be filled. 


\section{Implementing}

In this phase, the researcher and teacher execute the plan that has been agreed before. In each meeting, the researcher as an observer records the learning activities. It is also assisted by one of the collaborators as the observer and the other one plays a role as the teacher. In the first meeting, the steps of the scientific-based approach are realized in the main activities. For instance, in the step of observing, students are asked to pay attention to the provided topics of texts. Under the teacher's guidance, students analyze the texts dealing with generic structures, contents, and linguistic aspects. Subsequently, the_students start giving comments relating to the topic of the texts. In this context, feedback is promising input for developing the four language skills (Wahyuni, et. al., 2019; Brumen, et al., 2018; Sumekto \& Setyawati, 2019; Septiana \& Kadarisman, 2016).

\section{Evaluating}

Having done the action, it is important to see every progress of students' classroom interaction and achievement. The evaluation is conducted by the teacher and the researcher. The researcher assisted by the observer notices the classroom process at every meeting in the first cycle. From the first meeting into the fourth meeting, the researcher and the teacher evaluate the students' progression of generic structure of the conversation text, content, vocabulary acquisition, and students' attitudes such as respecting classmates and the teacher in the class. In addition, the researchers evaluate the interaction between students and the teacher that occurs but it is no significant changes among students and between the teacher and students.

In the last meeting, students are provided a test to know their English achievement after conducting the actions. The researcher and the teacher distribute a test. A test is administered in line with the indicators of basic competences breaking down from the core competencies. Based on the result of descriptive analysis, the score of students can be seen in Table 3 as follows.

Table 3. The Students' ELT Achievement at Cycle 1

\begin{tabular}{lll}
\hline \multicolumn{2}{l}{ Statistics } & \\
\hline Score & & \\
\hline $\mathrm{N}$ & Valid & 21 \\
\cline { 2 - 3 } & Missing & 0 \\
\hline Mean & & 74.48 \\
\hline Median & & 70.00 \\
\hline
\end{tabular}




\section{Reflecting}

\begin{tabular}{ll}
\hline Mode & 68 \\
\hline Std. Deviation & 8.646 \\
\hline Minimum & 60 \\
\hline Maximum & 88 \\
\hline Sum & 1564 \\
\hline
\end{tabular}

In Cycle 1, it can be concluded that the use of the scientific-based approach was not effective to solve all of the students' problems in the ELT classroom. Cycle 1 indicated that some problems faced by students were solved by using the approach. Those problems included (1) students have difficulties to understand the teacher's instruction to complete their learning tasks, (2) students do not have enough vocabulary acquisition to complete reading tasks, and (3) students have lack of grammatical competence to arrange sentences. Based on the students' problems solved in Cycle 1, the researcher and the teacher agreed to continue to the second cycle (cycle 2). The teacher and the researcher in the next cycle were focused on different students' problems.

\section{Cycle 2}

\section{Planning}

The previous cycle was addressed to some learning problems faced by students in ELT classrooms. Those were solved by using the scientific-based approach, but other problems would be handled in the second cycle by applying the same approach. The learning approach was actually applied in line with the feasible learning problems which are urgent to be elucidated. In this second cycle, the action is focused on students' problems dealing with speaking abilities, asking activities, and listening activities. The use of the scientific-based approach along with the proper learning materials and teaching media is prepared well. It is in line with what Indrilla (2018) states the scientific approach is effective to improve the $8^{\text {th }}$-grade students' language acquisition. Also, Astuti (2015) and Sarwanti (2016) state the scientific approach is possible for English teachers to improve students' language skills.

\section{Implementing}

As mentioned in the planning, the learning activities are directed to involve students in learning activities oriented to speaking abilities. The teacher has divided students into 3-4 students of each group. Each group is asked to observe any classroom pictures. The teacher carries out question-answer activities about the pictures. Thus, the teacher provides students 
with some exercise to ask questions in English correct grammar. The students practice to imitate the sentences in groups between each member. Besides, students are asked to associate the topic being discussed with other relevant topics in their question-answer activities. In short, the cycle is oriented to those problems going to solve.

\section{Evaluating}

Having done the implementation, the researcher and the teacher evaluate the students' progress relating to students' speaking ability, questioning activities, and listening activities. In the first meeting, students are directed to practice speaking skills through discussion activities. The teacher provides interesting materials for students such as giving serial pictures and some videos. It is intended to help students acquire ideas to practice expressing their ideas in English. In doing so, the teacher divided students into small groups. The learning process occurs in the form of group discussion. The interaction is done in a dynamic discussion and almost all of the students are involved. The three steps of the scientific-based approach are employed in this meeting, namely observing, asking, and associating activities.

The activities are focused on practicing to express opinions through speaking activities from the first meeting into fourth meeting. To strengthen students' speaking abilities, the teacher provides the topics of Sasak traditional music such as rudat and gendang beleq. It is in accordance with what Haerazi et al. (2018) and Aprianoto et al. (2018) recommend that cultural topics are promising inputs to evoke the_students' speaking competences. To facilitate students in doing so, the teacher offers students with interesting materials in the form of videos. Huang and Hung (2012) state video can help students to augment their English speaking skills. In addition, video is used to evoke students' attention (Kuo et al., 2014). According to the teacher, the learning processes are quite successful to facilitate students to familiarize themselves with native accents and pronunciation and to acquire new vocabulary. It is also proved by the result of students' achievement in cycle 2 .

Table 4. The Students' Achievement at Cycle 2

\begin{tabular}{llr}
\hline \multicolumn{3}{c}{ Statistics } \\
\hline Score & & \\
\hline $\mathrm{N}$ & Valid & 21 \\
\cline { 2 - 3 } & Missing & 0 \\
\hline Mean & & 82.76 \\
\hline Median & & 80.00 \\
\hline
\end{tabular}




\begin{tabular}{lr}
\hline Mode & 80 \\
\hline Std. Deviation & 3.820 \\
\hline Minimum & 78 \\
\hline Maximum & 90 \\
\hline Sum & 1738 \\
\hline
\end{tabular}

Reflecting

The researcher and the teacher agreed that the implementation of the scientific-based approaches was able to enhance students' achievement and classroom interaction by providing interesting learning materials. The students' problems were solved in two cycles. Cycle 1 was focused on the students' problems relating to (1) students' difficulties to complete their learning tasks, (2) lack of vocabulary to complete reading tasks, and (3) lack of grammatical competence. Meanwhile, Cycle 2 was addressed to help students to eradicate that they feel still (1) afraid of proposing questions, (2) afraid of speaking, and (3) difficulties to complete the listening tasks. In the second cycle, the result showed that almost $95 \%$ of students diminished their learning problems in the ELT class.

\section{CONCLUSION}

Having done the action in two cycles, the researcher concludes that the use of the scientific-based approach for $8^{\text {th }}$ grade students of SMPN 4 Praya is effective to solve students' problems dealing with students' difficulties in completing their learning tasks, lack of vocabulary acquisition to complete reading tasks, lack of grammatical competence, afraid of submitting questions, afraid of speaking in the class, and difficulties in conducting listening tasks. The steps of the scientific-based approach include observing, questioning, collecting, associating, and communicating. By providing students with various interesting learning activities, assisted by interesting learning tasks and materials, students are able to involve themselves in the teaching-learning activities in the class. In addition, students brave to express their ideas or opinions in English although the utterances are in simple sentences.

To solve those students' problems, the teacher provided for students with familiar topics to discuss in the form of small groups. In Cycle 1, the researcher and the teacher conducted the actions in four meetings. The fifth meeting was allotted to carry out the final test to know the students' progress. The effect of the scientific-based approach in the $1^{\text {st }}, 2^{\text {nd }}$, and $3^{\text {rd }}$ meetings was not seen yet. The effect of that approach could be seen in the $4^{\text {th }}$ meeting. The mean score of students' achievements was 74.48. It indicated that the passing grade was achieved classically but not individually because of some students' scores under the minimum achievement criteria. 
The significant change in this cycle was that the students are able to diminish their learning difficulties. In cycle 2, the actions are done in four meetings. The interaction among students and between students and the teacher improved. It was proved that the mean score of students' achievements was 82.76. The passing grade was achieved individually in the second cycle.

\section{SUGGESTION}

The teacher can keep going to use the scientific-based approach in the teaching of ELT classroom for Junior high schools to overcome students' problems relating to the students' achievement and classroom interaction. The problems derive from some difficulties such as (1) students' difficulties to complete their learning tasks, (2) lack of vocabulary to complete reading tasks, and (3) lack of grammatical competence, (4) afraid of proposing questions, (5) afraid of speaking, and (6) difficulties to complete the listening tasks. Based on the result, the teacher can apply this approach regularly to maintain and improve the students' achievement and classroom interaction. Also, the teacher should give more guidance and clues when they complete learning tasks to make the implementation of that approach more effective in the class or out of the class. Besides, the teacher also should consider time management as effectively as possible and ensure that students have enough time to do the learning activities.

\section{REFERENCES}

Aprianoto, Maurisa, S., \& Haerazi (2018). Developing instructional tasks and materials of interculture-based English speaking skills (IBES) model, Journal of Arts, Science, \& Commerce, Vol. IX (October), 57-64. http://dx.doi.org/10.18843/rwjasc/v9i4/08

Astuti, D. (2015). Efektivitas pendekatan saintifk terhadap keterampilan menulis karangan narasi di kelas IV SD Jomblangan, Bantul. Basic Education, 4(3), 1-10

Brumen, M., Zupančič, T., Agüero, M. F., \& Alonso-Belmonte, I. (2018). Foreign language teachers' feedback practices: A comparative study. New Educational Review, 53(3), 216226. https://doi.org/10.15804/tner.2018.53.3.18

Constello, P. (2011). Effective action research: Developing reflective thinking and practice (2 $2^{\text {nd }}$ edition). London: Continuum International Publishing Group.

Elliot, J. (1991). Action research for educational change. Philadephia: Open University Press. 
Haerazi, Irwansyah, D., Juanda, \& Azis, Y. A. (2018). Incorporating intercultural competences in developing english materials for writing classes, Journal of Language Teaching and Research, 9(3) 540-547 http://dx.doi.org/10.17507/jltr.0903.13

Haerazi, H., \& Irawan, L. A. (2019). Practicing Genre-Based Language Teaching Model to Improve Students' Achievement of Writing Skills. IJELTAL (Indonesian Journal of English Language Teaching and Applied Linguistics), 4(1), 9-18. http://dx.doi.org/10.21093/ijeltal.v4i1.246

Huang, H. T. D., \& Hung, S. T. A. (2013). Exploring the utility of a video-based online EFL discussion forum. British Journal of Educational Technology, 44(3), 90-95. https://doi.org/10.1111/j.1467-8535.2012.01373.x

Indrilla, N. (2018). The effectiveness of scientific approach and contextual teaching and learning approach in teaching writing. Lingua Cultura, 12(4), 405. https://doi.org/10.21512/lc.v12i4.4452

Kemendikbud. (2016). Media komunikasi dan inspirasi: Jendedal pendidikan dan kebudayaan (Empat perbaikan kurikulum 13). Jakarta: Redaksi Kemendikbud.

Kristie, L. S., \& Listyani (2018). Teachers' strategies to improve students' self-confidence in speaking, Register Journal, 11(2), 139-153. http://doi.org.10.18326/rgt.v11i2.139-153

Kuo, Y.-L., Lee, J.-S., \& Hsieh, M.-C. (2014). Video-based eye tracking to detect the attention shift. International Journal of Distance Education Technologies, 12(4), 66-81. https://doi.org/10.4018/ijdet.2014100105

Munir, A. (2015). Claims of scientific approach in an English lesson transcript, Universitas Negeri Surabaya, Bahasa \& Sastra Inggris, (9 December 2016). https://doi.org/10.26740/parama.v2i2.1511

Nooryastuti, N.A. (2015). Developing scientific approach-based learning materials for grade VIII students of Junior High School in Yogykarta. Thesis, Applied Linguistic Study Program, State University Yogyakarta.

Nur, M. R. \& Madkur, A. (2014). Teachers' voices on the 2013 curriculum for English instructional activities. IJEE, 1(2), 119-133.

Sarwanti, S. (2016). Scientifc method in English language teaching. Transformatika: Jurnal $\begin{array}{llll}\text { Bahasa, Sastra, } \quad \text { dan } & \text { Pengajarannya, }\end{array}$ http://jurnal.untidar.ac.id/index.php/transformatika/issue/view/17 
Septiana, A. R., Sulisyo, G. H., \& Kadarisman, A. E. (2016). Corrective feedback and writing accuracy of students across different levels of grammatical sensitivity. Indonesian Journal of Applied Linguistics, 6(1), 1-11. https://doi.org/10.17509/ijal.v6i1.2642

Sodik, F., \& Wijaya, M. S. (2017). Implementing scientific approach of 2013 curriculum at KTSP-based school for teaching present continuous tense, English Education: Journal Tadris Bahasa Inggris, 10(1), 16-28.

Sumekto, D. R., \& Setyawati, H. (2019). Measuring peer feedback on writing class: A study on third-semester pre-service English teachers, Lingua Cultura, 13 (1) 45-53. https://doi.org/10.21512/lc.v13i1.5058

Syafii, M. L. (2018). Using online short stories to improve the reading comprehension ability. Register Journal, 11(2), 168. https://doi.org/10.18326/rgt.v11i2.168-191

Wahyono, Abdulhak, I., \& Rusman. (2017). Implementation of scientific approach based learning to think high level in State Senior High School in Ketapang, International Journal of Education and Research, 5(8), 221-230.

Wahyuni, A. D., Zainil, Y., \& Oktavia. (2019). An analysis of teachers' feedback on students' writings at SMAN 4 Padang, Journal of English Language Teaching, 8(2), 54-62. http://ejournal.unp.ac.id/index.php/jelt.

Yoshida, I. (2010). Teacher vs students: The perspective on cognitive skills in foreign language learning. The $24^{\text {th }}$ JLTANE.

Zaim, M. (2017). Implementing Scientific Approach to Teach English at Senior High School in Indonesia, Journal of Canadian Center of Science and Eduaction, 13(2), 33-40. https://doi.org/10.5539/ass.v13n2p33 